\title{
Sampling and Analysis Techniques for Odorous Volatile Organic Compounds (VOCs) from Concentrated Aged Sidestream Smoke (SSS)
}

\author{
by \\ H.J.Taylor ${ }^{1}$, D.B.Winter ${ }^{1}$, E.J.F.Miranda ${ }^{2}$, and J.R.Pereira.da Silva ${ }^{2}$ \\ ${ }^{1}$ Group Strategic Research, British American Tobacco, Southampton, U.K. \\ 2 Souza Cruq, $R$ \& D Center, Rio de Janeiro, Brasil.
}

\section{SUMMARY}

This work is part of a long term study aimed at determining the odorous Volatile Organic Compounds (VOCs) in Environmental Tobacco Smoke (ETS) deposited on clothing. In this preliminary phase of the study sidestream smoke (SSS) rather than true ETS was used, for the following reasons. Firstly, the sampling system had to be modified in order to increase the concentration of odorous VOCs collected so that the later analytical stages could proceed. This meant that the sampling system was developed to collect concentrated SSS on cloth. Secondly, the cigarette butts were removed from the system so that they did not contribute to the odour; and thirdly the cloth was left to age for 48 hours. Therefore, technically, the study was the determination of the odorous VOCs in aged concentrated SSS deposited on cloth; this will be referred to as 'aged SSS' from this point onwards throughout this paper.

This paper describes the method development of sampling and analysis techniques for odorous VOCs in aged SSS deposited on cloth. In addition, this paper demonstrates the processes of heartcutting and the mass spectral identification of odorous components using a concentrated tobacco steam distillate extract.

A sampling chamber was constructed to allow the aged SSS to be deposited on the surface of the fabric, and to ensure that the amount of smoke deposited on the cloth was sufficiently high to conduct further analyses. The fabric was then desorbed via a purpose built purgeand-trap system to release the volatiles onto selected adsorbents. Each adsorbent in turn was solvent desorbed and a concentrated extract obtained. The aged SSS extracts were then directly injected into a multidimensional Gas Chromatography/Mass Spectrometry (GC/MS), and GC profiles obtained. These chromatographic profiles facilitate both the direct comparison of the range of VOCs trapped and desorbed from each adsorbent, and the identification of odorous regions when used in conjunction with the odour port. The aged SSS chromatograms presented in this paper only show the range of VOCs collected by the different adsorbents. Further experiments were also conducted with a concentrated tobacco steam distillate extract. These results were obtained by directly injecting the extract into the multidimensional GC/MS system, connected to an odour port. Volunteers were then asked to sensorially evaluate the odour of the extract and to identify any odorous notes during the analysis. Two concentrated tobacco steam distillate extract chromatograms are presented. [Beitr. Tabakforsch. Int. 18 (1999) 175-187]

\section{ZUSAMMENFASSUNG}

Die Arbeit ist Teil einer Langzeituntersuchung zur Bestimmung geruchsverursachender flüchtiger organi- 
scher Verbindungen [volatile organic compounds (VOCs)] im Tabakrauch der Raumluft [environmental tobacco smoke (ETS)], der sich auf Textilien abgelagert hat. In dieser Pilotphase der Studie wurde Nebenstromrauch (NSR) [sidestream smoke (SSS)] aus folgenden Gründen statt ETS eingesetzt: Um die Konzentration der gesammelten geruchsbildenden VOCs zu erhöhen und damit die nachfolgenden analytischen Untersuchungen durchführen zu können, mußte erstens das Sammelsystem verändert werden. Dies bedeutete, dass eine Vorrichtung zum Sammeln konzentrierten Nebenstromrauchs auf Stoffgewebe entwickelt wurde. Zweitens wurden die Cigarettenstummel aus dem System entfernt, so dass diese nicht zur Geruchsbildung beitrugen, und drittens wurde das Textilstück während 48 Stunden zur Alterung in der Sammelvorrichtung belassen. Somit untersuchten wir in der Studie technisch gesehen geruchsverursachende VOCs in gealtertem konzentriertem NSR, die sich auf Stoffgewebe abgelagert hatten. Nachfolgend sprechen wir bei der Beschreibung dieses Phänomens von ,gealtertem NSR' ['aged SSS‘].

Diese Arbeit beschreibt die Methodenentwicklung zum Sammeln und zur Analyse geruchsbildender VOCs in gealtertem, auf Textilien abgelagertem NSR. Zusätzlich wird das Verfahren des ,Heartcutting' beschrieben sowie die massenspektrometrische Identifizierung geruchsbildender Verbindungen anhand eines mittels Wasserdampfdestillation gewonnenen konzentrierten Tabakextrakts.

Eine Auffangkammer wurde derart konstruiert, dass sich der gealterte NSR auf der Oberfläche des Gewebestücks niederschlagen konnte und die Konzentration der auf dem Stoffstück abgelagerten Rauchmenge groß genug war, um weitere Analysen zu ermöglichen. Das Stoffgewebe wurde dann mit Hilfe einer zu diesem Zweck konstruierten ,Purge and Trap'-Vorrichtung desorbiert, wobei die flüchtigen Bestandteile an ausgewählten Adsorbentien niedergeschlagen wurden. Jedes Adsorbens seinerseits wurde mit einem Lösungsmittel extrahiert und so ein angereichertes Extrakt erhalten. Die gealterten NSRExtrakte wurden dann direkt in ein mehrdimensionales gaschromatographisch-massenspektrometrisches (GC-MS) System eingespritzt und GC-Profile erstellt. Diese Gaschromatogramme erleichtern sowohl den direkten Vergleich der verschiedenen aufgefangenen und von den einzelnen Adsorbentien freigesetzten VOCs als auch die Identifizierung geruchsverursachender Substanzen, wenn ein Port zur sensorischen Geruchswahrnehmung gekoppelt wurde. Die Chromatogramme des in dieser Arbeit beschriebenen gealterten NSR zeigen lediglich die verschiedenen durch unterschiedliche Adsorbentien angereicherten VOCs. Weitere Experimente wurden mit einem mittels Dampfdestillation gewonnenen konzentrierten $\mathrm{Ta}$ bakextrakt durchgeführt. Hierbei wurde das Extrakt direkt in ein mehrdimensionales GC-MS-System, an das ein Geruchsport gekoppelt war, eingespritzt. Freiwillige wurden dann gebeten, den Geruch des Extrakts sensorisch zu bewerten und bestimmte Geruchsnoten während der Analyse zu identifizieren. Zwei Chromatogramme von konzentriertem Tabakdampfdestillat werden präsentiert. [Beitr. Tabakforsch. Int. 18 (1999) 175-187]

\section{RESUME}

Ce travail fait partie d'une étude à long terme visant à déterminer les composés organiques volatils (COV) [volatile organic compounds (VOCs)] dans la fumée de tabac ambiante (FTA) [environmental tobacco smoke (ETS)] déposés sur un tissu. Dans une phase préliminaire de l'étude, la fumée du courant secondaire (CS) [sidestream smoke (SSS)] a été utilisée pour des raisons suivantes: Premièrement, le système collecteur a été modifié de manière à accroître le rendement en COVs afin de faciliter les essais analytiques. Pour cela, un système collecteur a été mis au point pour recueillir le CS sur le tissu. Deuxièmement, les mégots de cigarettes ont été éliminés du système pour empêcher qu'ils influencent l'odeur; troisièmement, le tissu a été laissé dans le système pour un "vieillissement" pendant 48 heures. Du point de vue technique, le but de cette étude était de déterminer les COVs odorants dans le CS “vieilli" déposé sur un tissu. Dans cette étude l'expression "CS vieilli” ['aged SSS'] sera utilisée pour dénommer ce phénomène.

Cette étude décrit les techniques mises au point pour recueillir et analyser les COVs odorants dans le CS déposé dans un tissu. En outre, cette étude démontre le processus de dégradation et l'identification par spectrométrie de masse de substances odorantes au moyen d'un extrait de tabac concentré obtenu par distillation à la vapeur.

Une chambre "collecteur" a été construite pour permettre que le "CS vieilli" se dépose sur la surface du tissu et garantisse que la quantité de fumée déposée sur le tissu soit suffisamment grande pour permettre la poursuite d'analyses complémentaires. Ensuite les substances fixées sur le tissu sont extraites par un dispositif purgeur/collecteur développé dans ce but pour enrichir les substances volatiles avec des adsorbants sélectionnés. Chacun des adsorbants a été relargué au moyen d'un solvant afin d'obtenir un extrait enrichi. Les extraits du "CS vieilli" ont ensuite été introduit dans un système de chromatographie en phase gazeuse combiné à la spectrométrie de masse (GC-MS) et les profils GC des composés ont été obtenu. Ces profils chromatographiques ont facilité la comparaison directe des divers COVs recueillis et relargués par des adsorbants spécifiques de même que l'identification 
de régions odorantes si le dispositif expérimental était combiné à un olfactomètre. Dans cette étude, les chromatogrammes du "CS vieilli" obtenus montrent seulement les divers COVs recueillis par les adsorbants particuliers.

Des essais complémentaires ont été réalisés avec un extrait concentré de tabac obtenu par distillation à la vapeur. Cet extrait a été introduit directement dans un appareil GC/MS, combiné à un olfactomètre. Des volontaires ont ensuite évalué sensoriellement l'odeur de l'extrait et identifier chacune des nuances au cours de l'analyse. Deux chromatogrammes d'extraits de tabac obtenus par distillation à la vapeur sont présentés. [Beitr. Tabakforsch. Int. 18 (1999) 175-187]

\section{INTRODUCTION}

Cigarette smoking generates a complex dynamic aerosol, which contains thousands of chemicals (1, 2, 3 ), mainstream smoke (MSS) is formed during puffing and SSS is formed during smoulder. As the SSS and exhaled MSS diffuse into the atmosphere and away from the cigarette and smoker, they become greatly diluted, and cool to form ETS (4). Therefore, concentrated SSS and exhaled MSS are physically and chemically different to ETS $(5,6)$. It is known that during the process of forming ETS, VOCs distil out of the smoke particles $(5,7)$, some of these are odorous in nature $(8,9,10)$. It was the intention of this study to identify the odorous VOCs in ETS.

It has been shown by BAKER and PROCTOR (7) that exhaled MSS contributes $15-43 \%$ to the ETS particulate phase, $1-9 \%$ to the ETS nicotine, and 3-13\% to the ETS CO. Therefore, exhaled MSS contributes little to the gas phase of ETS, and it is SSS that is the major contributor.

The first part of this paper describes the sampling procedures for odorous VOCs from aged SSS deposited on cloth, through to production of odorous solvent extracts from six different adsorbents. Each adsorbent was chromatographically assessed for the range of VOCs that were detected.

The second part of this paper describes the simultaneous separation and sensorial assessment of the odorous VOCs from a tobacco steam distillate extract using Gas Chromatography/Olfactometry $(\mathrm{GC} / \mathrm{O})(11,12)$. This was included to demonstrate Aroma Extract Dilution Analysis (AEDA) (13), and the use of the multidimensional GC/MS system, including heartcutting and mass spectral identification $(14,15)$.

This technique works on the principle that the GC column separates the components of the mixture, which are then split into 2 portions (15). A portion is sent to an olfactometer (or odour port) where it is combined with humidified and purified air before being presented to a human assessor; and the remainder to a Flame Ionisation Detector (FID) where the components are detected. At the odour port, upon perceiving an odour the human assessor describes the odour, and notes the GC retention time, such that the odour descriptors can be related to a FID signal.

The potency of the odours can be determined by using AEDA. AEDA is the collection and serial dilution of a concentrated solvent extract, which is then injected into a GC/O (where a human panellist sniffs the GC effluent and assesses it for odour potential). In AEDA several dilutions are injected and assessed, such that at the highest dilutions only the most potent odours are sensed. The principle is that the most potent odours detected in a mixture should contribute most to the overall mixture aroma (13).

\section{EXPERIMENTAL DETAILS}

Reagents

Adsorbent materials Tenax TA 60-80 mesh, Carbopack B 60-80 mesh, Carbopack C 60-80 mesh, Carboxen 60-80 mesh, Carboxen 20-45 mesh, and activated charcoal 20-40 mesh, were purchased from Supelco Inc. The $100 \%$ cotton was purchased from Choice Cuts, Southampton. The unsilanised glass wool and the dichloromethane (pesticide grade -99.99\% purity) were purchased from Fisher Scientific International Co. The ethanol (99.7 \% purity) was purchased from Hayman Ltd. The helium (99.0\% purity), and liquid carbon dioxide $(99.9 \%$ purity) were purchased from Air Products Ltd. The solid carbon dioxide was made from a carbon dioxide cylinder (99.9\% purity) which was purchased from Air Products Ltd.

\section{Instrumentation}

Separations were performed on a Hewlett Packard (HP) 6890 Gas Chromatograph (GC) equipped with a HP 5973 Mass Selective Detector (MSD) connected to an Edwards' vacuum pump. The HP system was connected to a Scientific Glass Engineering (SGE) multidimensional (MDS) 2000 system. The HP 6890 GC oven housed two capillary columns, the first was a J \& W Scientific (Jones Chromatography) DB-1, $30 \mathrm{~m}$ long, $0.25 \mathrm{~mm}$ I.D., $1.0 \mu \mathrm{m}$ film thickness fused silica column. The second column was a J \& W Scientific (Jones Chromatography) DB-210, 30 $\mathrm{m}$ long, $0.25 \mathrm{~mm}$ I.D., $0.5 \mu \mathrm{m}$ film thickness fused silica column. 
The adsorbent packed GC liners were conditioned prior to use in a Carlo Erba 6000 Series II GC.

For the thermal desorption stage, the adsorbent packed GC liners were separately inserted into the split/splitless injection port of a HP 6890 GC which was connected to a J \& W Scientific (Jones Chromatography) DB-1, $60 \mathrm{~cm}$ long, $0.25 \mathrm{~mm}$ I.D., $1.0 \mu \mathrm{m}$ film thickness fused silica column.

For more detailed instrument conditions see Appendix 1.

\section{SAMPLING PROCEDURES}

\section{Collection of the sample on the cloth}

A sampling chamber was designed and constructed, which consists of a lower chamber and an upper chamber, with a hole cut between the two to allow access of the SSS. An ashtray containing the cigarettes to be smouldered is housed in the lower chamber, with a hanging system being employed in the upper chamber to drape 15 strips of $100 \%$ cotton. This is depicted in Diagram 1.

In our experiments, once the cotton was in place, four $100 \%$ Virginia cigarettes were smouldered in the lower chamber, and the 'fresh' SSS was allowed to disperse into the upper chamber and deposit on the strips of cotton. After all of the tobacco in the four cigarettes was consumed the smouldered cigarettes were removed, and the upper chamber was isolated from the lower chamber. This ensured that any odorous VOCs generated from cigarette butts did not contribute toward the odours collected on the cloth.
After isolation, the cloth was left in the upper chamber for 48 hours in a controlled temperature environment $\left(22^{\circ} \mathrm{C}\right)$.

This design allowed the SSS to be deposited on the surface of the fabric, and to ensure that the amount of smoke deposited on the cloth was sufficiently high to conduct further analyses $(16,17)$.

\section{Purging the cloth and collecting the VOCs on adsorbents}

After sampling, the 15 pieces of cotton (containing the deposited odorous VOCs) were removed from the upper chamber and transferred to a $300 \mathrm{~mL}$ volumetric flask (referred to as the purging vessel). This vessel was connected via tubing to four selected adsorbents (interchangeable from Tenax 60/80, Carbopack B 60/80, Carbopack C 60/80, Carboxen $60 / 80$, Carboxen $20 / 45$, and activated charcoal 20/40) housed in glass GC liners. The liner dimensions were $6.5 \mathrm{~mm}$ I.D. $\times 5 \mathrm{~mm}$ O.D. $\times 80 \mathrm{~mm}$ in length. Each of the GC liners was packed with 200 $\mathrm{mg}$ of adsorbent. The system was designed so that all four liners could be evaluated simultaneously using the same cloth sample. It also ensured that each liner was exposed to the same VOC headspace, and had the advantage of minimising the sampling time. The system is depicted in Diagram 2.

The vessel was purged at $200 \mathrm{~mL} / \mathrm{min}$ for 16 hours, which was required to recover the less volatile components; the flow rate through each adsorbent tube was maintained at $50 \mathrm{~mL} / \mathrm{min}$ using individual 12 $\mathrm{mm}$ diameter Vernier gauge flow restrictors. The flow rate was checked before and after sampling with a conventional bubble meter and the timer on the HP 6890 GC.

Pieces of cloth

Ashtray containing cigarettes

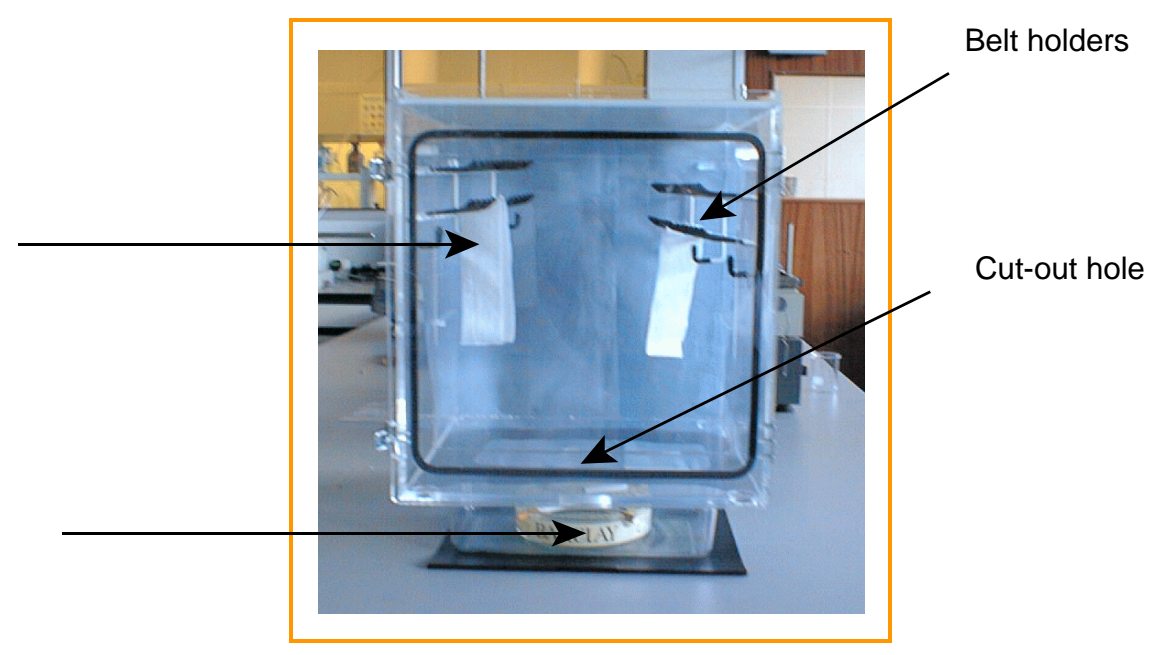

\section{Diagram 1.}

\section{Sampling chamber.}






\section{Diagram 2.}

Purging system.

\section{Adsorbents chosen}

The six adsorbents chosen were based upon:

- Range of collection

- Strength of trapping

- Retention of water vapour

- Affect of humidity changes

- Desorption efficiencies

- Safe sampling volumes

- Susceptibility to contamination

The top 3 factors were the most important for our analyses, and their characteristics are summarised in Table $1(18,19,20,21)$.

From viewing Table 1, it can be seen that the six adsorbents cover the sample range $\mathrm{n}-\mathrm{C} 2$ to $\mathrm{n}-\mathrm{C} 30$, which should encompass the VOCs of interest. We assessed adsorbents of different strength to determine the adsorption and desorption capacities; and finally attempted to choose adsorbents that were hydrophobic, so that they did not interfere with subsequent analyses.

\section{Conditioning the adsorbents}

All of the adsorbents were conditioned prior to use to ensure that they were clean and free from contamination. Each liner was conditioned at $280{ }^{\circ} \mathrm{C}$ for 1 hour, with a flow rate of $100 \mathrm{~mL} / \mathrm{min}$ helium, in a Carlo Erba 6000 Series II GC.

Thermally desorbing the adsorbent and cryotrapping the VOCs

Each adsorbent was placed separately in a HP 6890 GC injection port connected to a $60 \mathrm{~cm} \times 0.25 \mathrm{~mm}$ I.D. $\times 1.0 \mu \mathrm{m}$ film thickness, DB-1 capillary column. The capillary column was immersed in a Dewar containing ethanol and solid carbon dioxide; this was to cryotrap the VOCs upon desorption. All adsorbents were thermally desorbed at $250^{\circ} \mathrm{C}$ for 10 minutes with a helium flow rate through the column of 2 $\mathrm{mL} / \mathrm{min}$; except for activated charcoal which had to be desorbed for 30 minutes to remove all of the VOCs.

Table 1.

Properties of the selected adsorbents.

\begin{tabular}{|c|c|c|c|c|c|}
\hline Adsorbent & $\begin{array}{l}\text { Range of } \\
\text { compounds } \\
\text { collected }\end{array}$ & $\begin{array}{c}\text { Maximum } \\
\text { desorption } \\
\text { temperature } \\
\left({ }^{\circ} \mathrm{C}\right)\end{array}$ & $\begin{array}{l}\text { Surface area } \\
\qquad\left(\mathrm{m}^{2} / \mathrm{g}\right)\end{array}$ & $\begin{array}{l}\text { Adsorbent } \\
\text { strength }\end{array}$ & $\begin{array}{l}\text { Retention of } \\
\text { water }\end{array}$ \\
\hline Tenax 60/80 & $\mathrm{n}-\mathrm{C} 7$ to $\mathrm{n}-\mathrm{C} 30$ & 350 & $<50$ & Weak & No \\
\hline Carbopack B 60/80 & $\mathrm{n}-\mathrm{C} 4$ to $\mathrm{n}-\mathrm{C} 14$ & $>400$ & 100 to 500 & Medium & No \\
\hline Carbopack C 60/80 & $\mathrm{n}-\mathrm{C} 8$ to $\mathrm{n}-\mathrm{C} 20$ & $>400$ & $<50$ & Weak & No \\
\hline Carboxen 60/80 & $\mathrm{n}-\mathrm{C} 3$ to $\mathrm{n}-\mathrm{C} 9$ & 400 & 1000 & Strong & Some \\
\hline Carboxen 20/45 & $\mathrm{n}-\mathrm{C} 3$ to $\mathrm{n}-\mathrm{C} 9$ & 400 & 1000 & Strong & Some \\
\hline Activated charcoal $20 / 40$ & $\mathrm{n}-\mathrm{C} 2$ to $\mathrm{n}-\mathrm{C} 6$ & $>400$ & $>1000$ & Strong & Yes \\
\hline
\end{tabular}


After successfully cryotrapping the VOCs the column head was disconnected from the GC injection port and connected via an SGE butt connector to a gas tight syringe, with the column tail being pushed into a glass GC vial. Dichloromethane $(50 \mu \mathrm{L})$ was pushed through the column and stripped off the VOCs into the glass GC vial, producing a $50 \mu \mathrm{L}$ odorous concentrated extract for each adsorbent.

\section{ANALYTICAL PROCEDURES}

Aged SSS

Once an odorous concentrated extract had been obtained for each adsorbent, a $2 \mu \mathrm{L}$ aliquot was removed from each extract and injected separately via the HP 6890 split/splitless GC injection port.

Separation of the mixture occurred by passing through Column 1, $30 \mathrm{~m} \times 0.25 \mathrm{~mm}$ I.D. $\times 1.0 \mu \mathrm{m}$ film thickness, DB-1, followed by Column 2, $30 \mathrm{~m} \times$ $0.25 \mathrm{~mm}$ I.D. $\times 0.5 \mu \mathrm{m}$ film thickness, DB-210, (as shown in Diagram 3).

The column effluent passed a 1:4 splitter where it was divided. One fraction was sent to the MSD, and four fractions were sent to the FID (the compounds were detected by both instruments). At this stage no odour port work was performed on the aged SSS odour extract, and only GC profiles were obtained to compare the selected adsorbents, these are reproduced in the Results and Discussion section.

\section{Concentrated tobacco steam distillate extract}

In order to demonstrate heartcutting and the mass spectral identification of components, further experiments were conducted with a concentrated tobacco steam distillate extract of the standard cigarette using a multidimensional GC/MS system.

The principle of a multidimensional system is that it provides the analyst with two or more sets of data on a sample in a single analysis (it often applies to multiple column systems) (15). The SGE MDS 2000 system is a multiple column system, as shown in the Diagram 3.

Heartcutting is the selective removal of compounds of interest from a sample that requires further chromatographic separation; it allows the isolation of part of a sample. This is achieved by cutting a portion of the chromatogram from one column and transferring it to a second column, often of different polarity.

Using a $50 \mu \mathrm{L}$ concentrated tobacco steam distillate extract, a $25 \mu \mathrm{L}$ aliquot was removed and diluted with $25 \mu \mathrm{L}$ dichloromethane to produce a $1: 1$ diluted extract, this was further diluted to produce a series of diluted extracts. Each extract was

FID

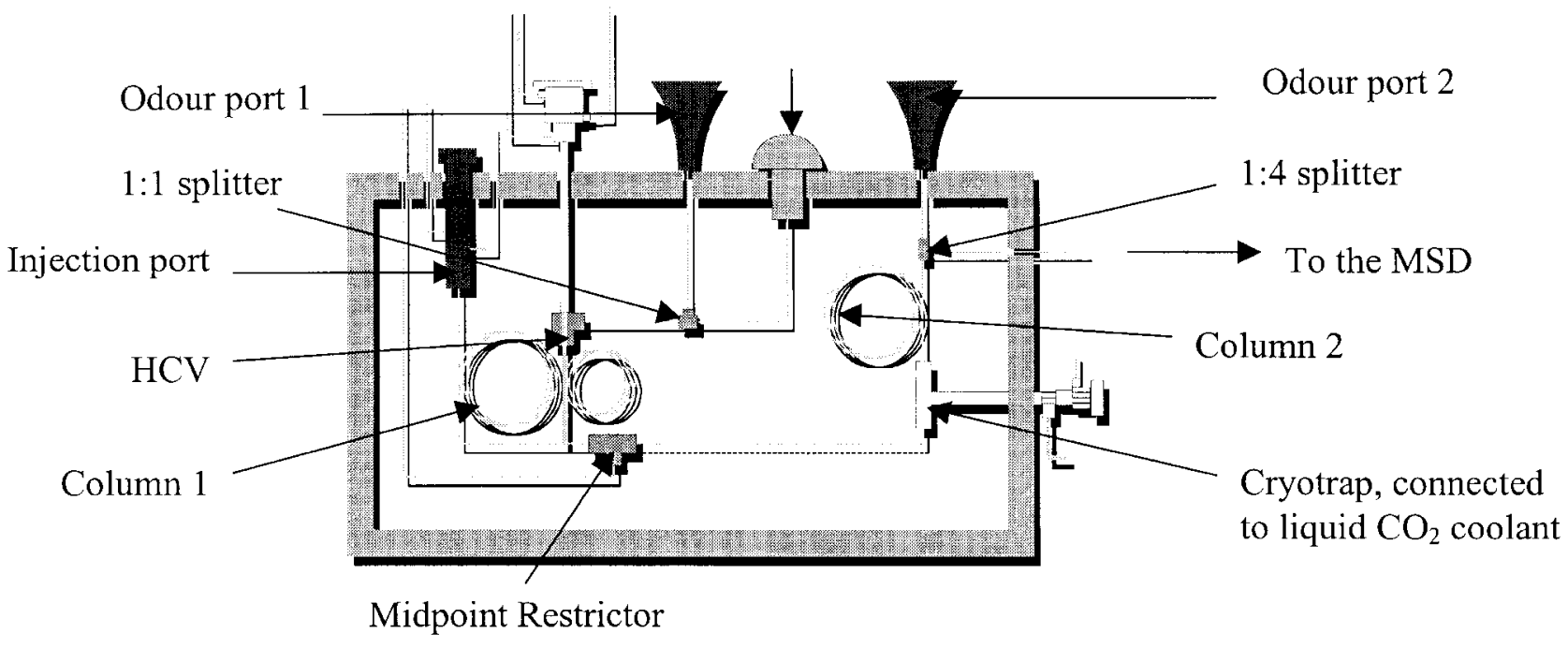

\section{Diagram 3.}

Multidimensional Heartcutting SGE System; FID = Flame Ionisation Detector, MSD = Mass Selective Detector, HCV = Heartcut Valve. 
separately (starting with the most dilute sample) injected via the HP 6890 split/splitless GC injection port into Column 1, $30 \mathrm{~m} \times 0.25 \mathrm{~mm}$ I.D. $\times 1.0 \mu \mathrm{m}$ film thickness, DB-1 (as shown in Diagram 3), and the mixture separated into individual components. These components reached the 1:1 splitter where they were equally divided between odour port 1 (where the human assessor perceived any potent odours and noted the retention time) and FID (where the compounds were detected). This procedure was performed several times with four different semi-trained human assessors; each extract was assessed three times per assessor. From these experiments aromagrams were plotted and the most potent odorous regions were identified.

Once the most potent odorous regions were identified from the tobacco steam distillate extract, the concentrated extract was injected via the GC injection port into Column 1, $30 \mathrm{~m} \times 0.25 \mathrm{~mm}$ I.D. $\times 1.0 \mu \mathrm{m}$ film thickness, DB-1. The co-eluting components were then heartcut by switching on the Heartcut Valve (HCV), which transferred the GC effluent through the midpoint to the cryotrap, which was cooled by liquid carbon dioxide. The cryotrap refocuses the heartcut fraction at the head of GC column 2, and the VOCs are held there until the next GC run. On the next GC run the liquid carbon dioxide coolant was turned off and the GC effluent transferred to Column $2,30 \mathrm{~m} \times 0.25 \mathrm{~mm}$ I.D. $\times 0.5 \mu \mathrm{m}$ film thickness, DB-210, where the heartcut peaks were separated further. The column effluent then passed a 1:4 splitter where it was divided. One fraction was sent to the MSD (where the compounds were detected and identified), and four fractions were sent to odour port 2 (where the human panellist confirmed the aromas of the previously detected odours).

\section{RESULTS AND DISCUSSION}

The chromatograms in Figure 1 highlight the range of VOCs collected by the different adsorbents, with the Tenax 60/80 collecting the widest range of VOCs.

The regions highlighted in the Figure 2 chromatogram (Column 1) were those that were heartcut onto Column 2, these were the main odour regions perceived by the four assessors. The three heartcut regions were 6.4 to $8.5,13.1$ to 14.5 , and 19.4 to 22.3 minutes.
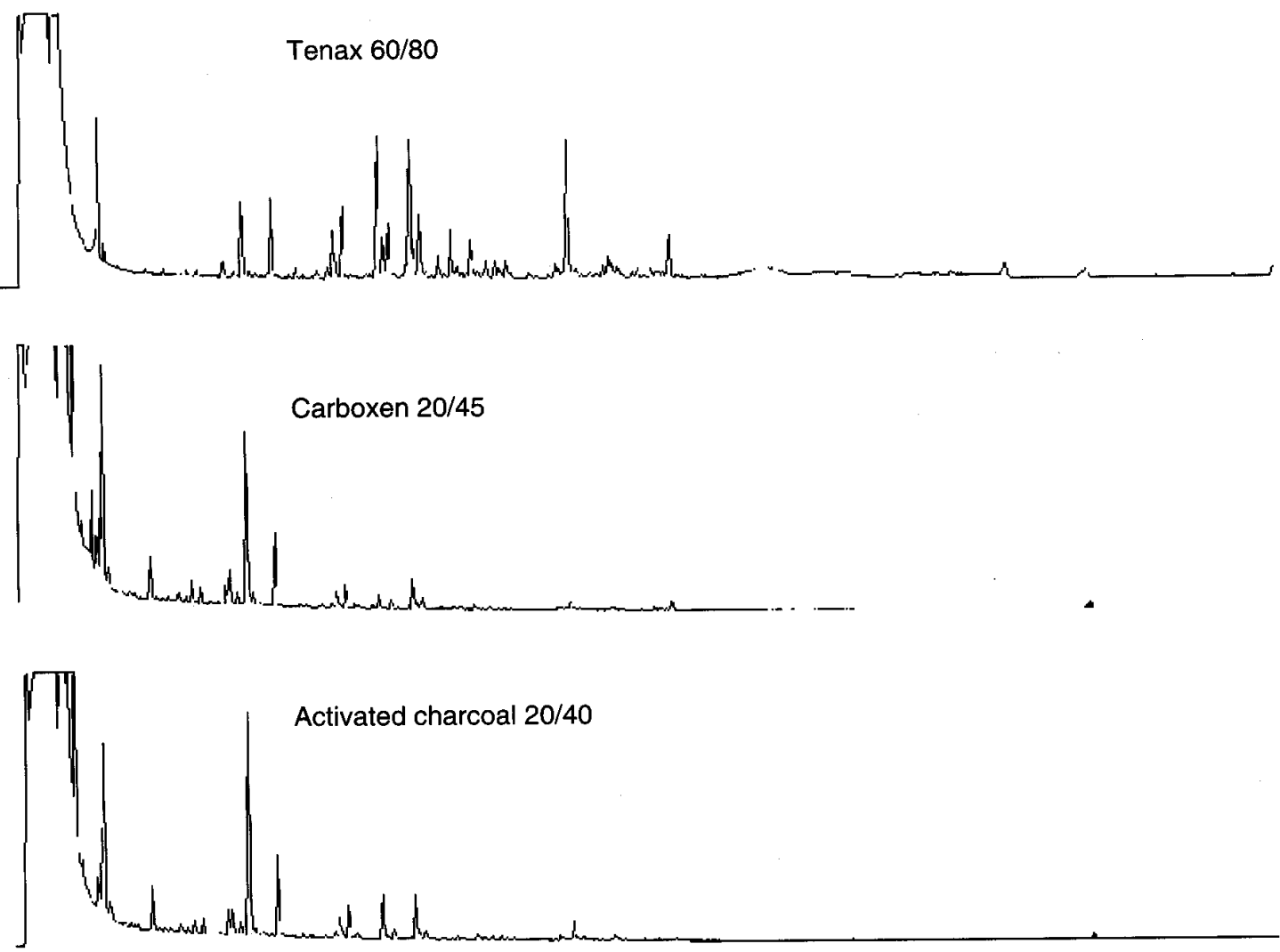

Figure 1.

Example chromatograms of VOCs collected from aged SSS by different adsorbents. 


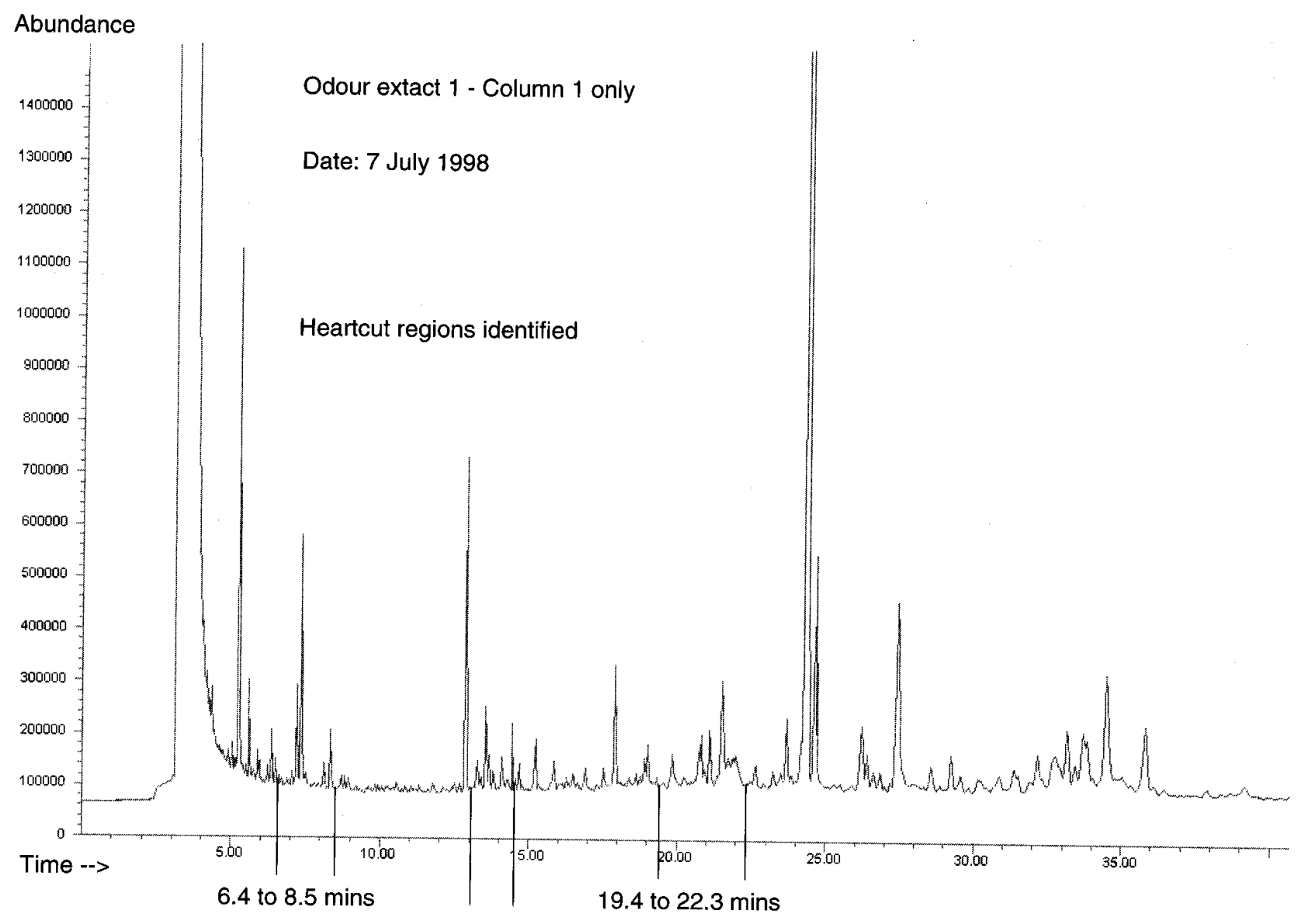

13.1 to 14.5 mins

\section{Figure 2.}

Chromatogram of concentrated tobacco steam distillate extract through Column 1 .

The odorous peak from the heartcut region (13.1 to 14.5 on Column 1) shown in Figure 3 was described as woody and floral. It was detected at 14.66 mins on Column 2, and was tentatively identified by mass spectrometry as $\beta$-damascenone. The other odorous peaks detected on Column 2 from the concentrated tobacco steam distillate extract are shown in Table 2.

\section{CONCLUSIONS}

This work has shown that it is possible to successfully trap VOCs from aged SSS collected on $100 \%$ cotton. The results also indicate that each adsorbent collects a different range of VOCs, with the Tenax $60 / 80$ collecting the widest range. Further work will be undertaken to perform odour port work on each adsorbent extract to determine which adsorbent traps the most potent odorous VOCs from aged SSS deposited on cloth, and identify individual odorous VOCs.
The concentrated tobacco steam distillate extract results indicate that by using the combined analysis procedures of AEDA, GC/O, heartcutting, and MSD, it is possible to assess and determine the most potent odorous regions, successfully separate co-eluting compounds, and tentatively identify them by means of mass spectrometry.

The main odour compounds tentatively identified from the tobacco steam distillate extract were acetaldehyde, phenyl acetaldehyde, and $\beta$-damascenone.

\section{REFERENCES}

1. Rodgman, A. and C.R. Green: The Tobacco Chemists' Research Conference: A half century forum for advances in analytical methodology of tobacco and its products; Recent Adv. Tob. Sci. 22 (1996) 131-304. 


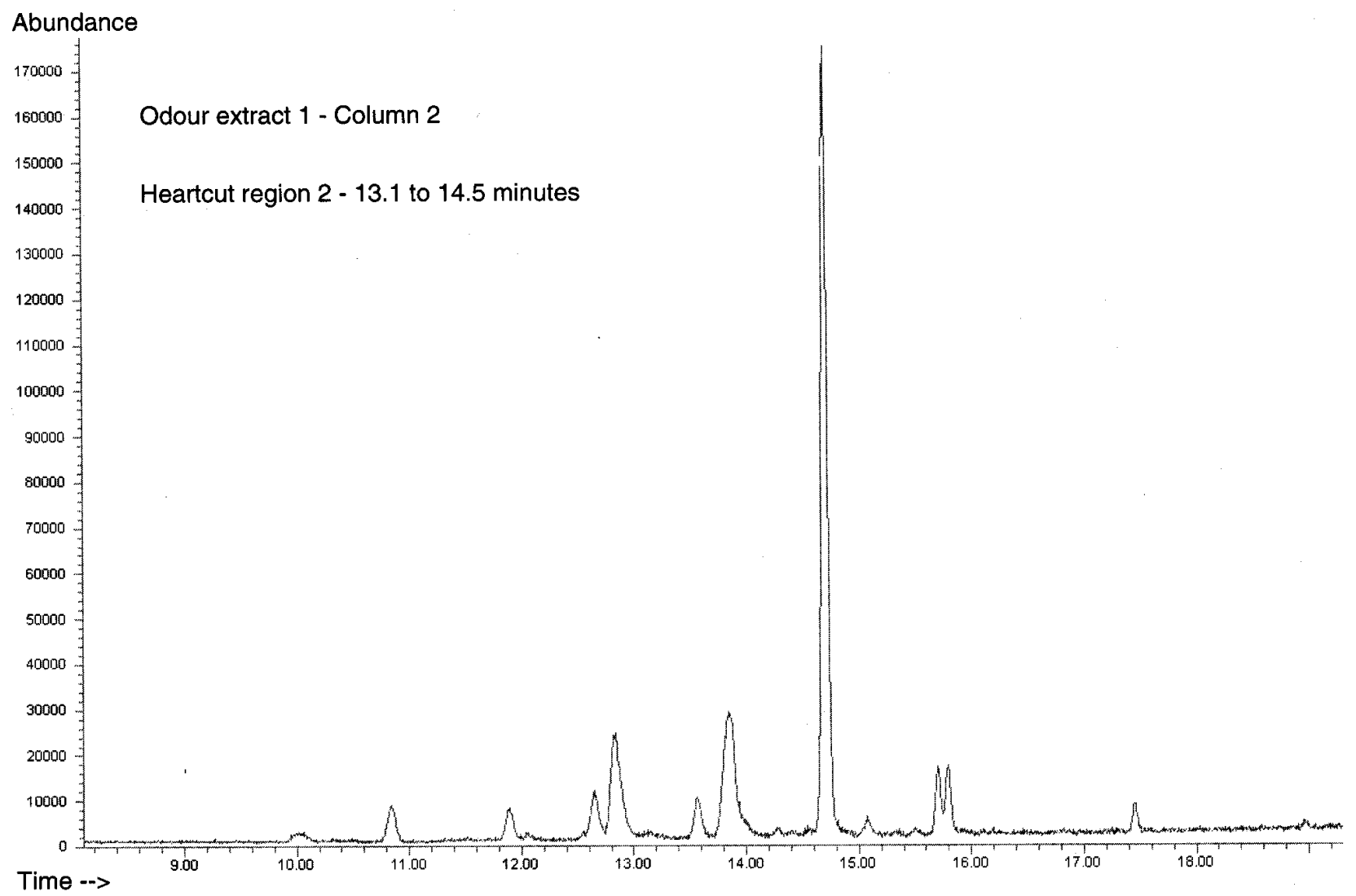

Figure 3.

Example chromatogram of heartcut region (13.1 to 14.5 minutes) from concentrated tobacco steam distillate extract through Column 2.

Table 2.

Preliminary mass spectral identifications of odorous components from concentrated tobacco steam distillate extract.

\begin{tabular}{l|c|c|c|c|c}
\hline $\begin{array}{l}\text { Heartcut } \\
\text { region }\end{array}$ & $\begin{array}{c}\text { Retention time of } \\
\text { the odour detected } \\
\text { from the } \\
\text { aromagram }\end{array}$ & $\begin{array}{c}\text { Retention time } \\
\text { on the GC } \\
\text { chromatogram } \\
\text { (minutes) }\end{array}$ & Odour descriptor & $\begin{array}{c}\text { Mass spectrum } \\
\text { (m/z) }\end{array}$ & $\begin{array}{c}\text { Preliminary } \\
\text { mass spectral } \\
\text { identification }\end{array}$ \\
\hline 1 & 6.70 to 7.20 & 6.82 & Ethereal/Chemical & $41,43,44$ & $\begin{array}{c}\text { Acetaldehyde } \\
\text { Phenyl }\end{array}$ \\
1 & 7.70 to 8.30 & 7.93 & Floral & $65,91,92,120$ & $\begin{array}{c}\text { acetaldehyde } \\
\text { B-damascenone } \\
\text { Peak below } \\
\text { LoD*, no match }\end{array}$ \\
\hline
\end{tabular}

*LoD - Limit of detection 
2. Particulate matter, 'tar', condensate: Seminars in Tobacco Science; Beitr. Tabakforsch. Int. 18 (1998) 53.

3. Dube, M.F. and C.R. Green: Methods of collection of smoke for analytical purposes; Recent Adv. Tob. Sci. 8. (1982) 42-102.

4. Guerin, M.R., R.A. Jenkins and B.A. Tomkins: Properties and measures of environmental tobacco smoke; in: The chemistry of environmental tobacco smoke: composition and measurement, edited by M. Eisenberg, Indoor Air Research Series, Center for Indoor Air Research (CIAR), Lewis Publishers, Inc., Chelsea, Michigan, 1992, pp 63-85.

5. Pritchard, J.N., A. Black and J.J. McAughey: The physical behaviour of sidestream tobacco smoke under ambient conditions; in: Indoor and ambient air quality, edited by R. Perry and P.W. Kirk, Selper, London, 1988, pp. 49-56.

6. Nelson, P.R., F.W. Conrad, S.P. Kelly, K.C. Maiolo, J.D. Richardson and M.W. Ogden: Composition of environmental tobacco smoke (ETS) from international cigarettes, Part II: Nine country follow-up; Environ. Int. 24 (1998) 251-257.

7. Baker, R.R. and C.J. Proctor: The origins and properties of environmental tobacco smoke; Environ. Int. 16 (1990) 231-245.

8. Guerin, M.R., R.A. Jenkins and B.A. Tomkins: Background indoor air contaminants; in: The chemistry of environmental tobacco smoke: composition and measurement, edited by $\mathrm{M}$. Eisenberg, Indoor Air Research Series, Center for Indoor Air Research (CIAR), Lewis Publishers, Inc., Chelsea, Michigan, 1992, pp 5-42.

9. Dravnieks, A. and A. O'Donnell: Determination of odor components in tobacco smoke: Design of a mixture to simulate odor; ASHRAE Trans. 81 (1975) 200-212.

10. Walker, J.C., D.B. Kurtz, F.M. Shore, M.W. Ogden, J.H. Reynolds: Apparatus for the automated measurement of the responses of humans to odorants; Chem. Senses 15 (1990) 165-177.

11. Drawert, F. and N.S. Christoph: Significance of the sniffing technique for determination of odor thresholds and detection of aroma impacts of trace volatiles; in: Analysis of volatiles, edited by P. Schreier, De Gruyter, Berlin, 1984, pp 269-291.

12. Dravnieks, A. and A. O'Donnell: Principles and some techniques of high resolution headspace analysis; J. Agricult. Food Chem. 19 (1971) 1049-1056.

13. Ullrich, F. and W.Z. Grosch: Identification of the most intense volatile flavor compounds formed during autoxidation of linoleic acid; Lebensm. Unters. Forsch. 184 (1987) 277- 282.
14. Schomburg, G., H. Hussman, L. Podmaniczky, F. Weeke and A. Rapp: Coupled gas chromatographic methods for separation identification and quantitative analysis of complex mixtures multidimension gas chromatography-mass spectrometry gas chromatography-IR and liquid chromatography-gas chromatography; in: Analysis of volatiles: methods, applications, edited by P. Schreier, De Gruyter, New York, 1984, pp 121.

15. Tomlinson, M.J. and C. L. Wilkins: Evaluation of a semi-automated multidimensional Gas Chromatography-Infrared-Mass Spectrometry system for irritant analysis; J. High Resol. Chromatogr. 21 (1998) 347-354.

16. Duc, T.V. and C.K. Huynh: Deposition rates of sidestream tobacco smoke particles in an experimental chamber; Toxicol. Lett. 15 (1987) 59-65.

17. Sims, J., P.A. Ellwood and H.J. Taylor: Pollutants from laser cutting and hot gas welding of plastics; Ann. Occup. Hyg. 37 (1993) 665-672.

18. U.K. Health and Safety Executive (HSE), Occupational Medicine and Hygiene Laboratory: Methods for the determination of hazardous substances (MDHS) 72, volatile organic compounds in air, laboratory method using pumped solid sorbent tubes; Her Majesty's Stationery Office (HMSO), Norwich, NR3 1BQ, February 1992.

19. U.S. Environmental Protection Agency (EPA), Compendium of methods for the determination of toxic organic compounds in ambient air: Methods TO-1 and TO-2; EPA/600/4-84-041, Research Triangle Park, NC 27711, April 1984.

20. U.S. Environmental Protection Agency (EPA), Compendium of methods for the determination of toxic organic compounds in ambient air: Compendium Method TO-17, Determination of volatile organic compounds in ambient air using active sampling onto sorbent tubes; EPA/625/R-96/010b, Cincinnati, OH 45268, January 1997.

21. SKC Guide to Air Sampling Standards, Scientific Kit Company Inc., PA 15330, U.S.A., 1989.

Address for correspondence:

Helen Taylor

British American Tobacco

Group Strategic Research

Regents Park Road, Southampton

GB-Hant SO15 8TL 
Conditions for assessing selected adsorbent extracts from aged SSS extract (GC effluent passing through column 1 and column 2).

\begin{tabular}{|c|c|c|c|}
\hline \multicolumn{2}{|c|}{ Olfactometer conditions } & \multicolumn{2}{|c|}{ GC/MSD conditions } \\
\hline \multirow[t]{10}{*}{ Odour port: } & $N / A$ & Injection mode: & Splitless \\
\hline & & Injection temperature: & $240^{\circ} \mathrm{C}$ \\
\hline & & Initial temperature: & $40{ }^{\circ} \mathrm{C}$ \\
\hline & & Initial time: & 0.5 mins \\
\hline & & Temperature ramp1: & $50{ }^{\circ} \mathrm{C} / \mathrm{min}$ to $50^{\circ} \mathrm{C}$ \\
\hline & & Temperature ramp2: & $5^{\circ} \mathrm{C} / \mathrm{min}$ to $240{ }^{\circ} \mathrm{C}$ \\
\hline & & Final time: & 5.0 mins \\
\hline & & Run time: & $43.70 \mathrm{mins}$ \\
\hline & & FID temperature: & $300^{\circ} \mathrm{C}$ \\
\hline & & MSD conditions: & $\mathrm{N} / \mathrm{A}$ \\
\hline
\end{tabular}

\section{SGE conditions}

$\begin{array}{llll}\text { Program: } & 3 & & \\ \text { Heartcut: } & 1 & \text { On }=0.01 \mathrm{mins} & \text { Off }=0.00 \mathrm{mins} \\ \text { Backflush: } & \text { N/A } & \text { On }=0.00 \mathrm{mins} & \text { Off }=0.00 \mathrm{mins} \\ \text { Split: } & 1 & \text { On }=0.50 \mathrm{mins} & \text { Off }=3.00 \mathrm{mins} \\ \text { Cryotrap: } & \text { N/A } & \text { On }=0.00 \mathrm{mins} & \text { Off }=0.00 \mathrm{mins}\end{array}$

Conditions for detection of odorous regions from concentrated tobacco steam distillate extract (Stage 1 GC effluent passing to column 1).

\begin{tabular}{llll}
\hline Olfactometer conditions & \multicolumn{2}{c}{ GC/MSD conditions } \\
\hline $\begin{array}{l}\text { Odour port: } \\
\text { Make up: }\end{array}$ & 1 & As above & \\
$\begin{array}{l}\text { Transfer gas: } \\
\text { Humidified air: }\end{array}$ & $3 \mathrm{~mL} / \mathrm{min}$ & & \\
\hline SGE conditions & $3 \mathrm{~mL} / \mathrm{min}$ & & \\
\hline Program: & & & \\
Heartcut: & 1 & & \\
Backflush: & N/A & On $=0.00 \mathrm{mins}$ & Off $=0.00 \mathrm{mins}$ \\
Split: & N/A & On $=0.00 \mathrm{mins}$ & Off $=0.00 \mathrm{mins}$ \\
Cryotrap: & 1 & On $=0.50 \mathrm{mins}$ & Off $=30.00 \mathrm{mins}$ \\
\hline
\end{tabular}


Conditions for heartcutting and cryotrapping from concentrated tobacco steam distillate extract (Stage 2 GC effluent is heartcut from column 1 to cryotrap).

\begin{tabular}{|c|c|c|c|}
\hline Olfactomet & & \multicolumn{2}{|c|}{ GC/MSD conditions } \\
\hline \multirow[t]{3}{*}{ Odour port: } & $\mathrm{N} / \mathrm{A}$ & \multicolumn{2}{|c|}{$\begin{array}{l}\text { As above, except for oven temperature conditions } \\
\text { which are different for each heartcut, see below. }\end{array}$} \\
\hline & & FID temperature: & On \\
\hline & & MSD conditions: & $N / A$ \\
\hline
\end{tabular}

\section{SGE and GC Temperature conditions}

\section{Heartcut 1, Region 1}

\begin{tabular}{llll}
\hline Program: & 2 & & \\
Heartcut: & 1 & On $=6.40 \mathrm{mins}$ & Off $=8.50 \mathrm{mins}$ \\
Backflush: & 1 & On $=8.51 \mathrm{mins}$ & Off $=18.00 \mathrm{mins}$ \\
Split: & 1 & On $=0.50 \mathrm{mins}$ & Off $=3.00 \mathrm{mins}$ \\
Split: & 2 & On $=8.51 \mathrm{mins}$ & Off $=18.00 \mathrm{mins}$ \\
Cryotrap: & 1 & On $=4.40 \mathrm{mins}$ & Off $=13.50 \mathrm{mins}$ \\
Initial temperature: & $40^{\circ} \mathrm{C}$ & & \\
Initial time: & $0.5 \mathrm{mins}$ & \\
Temperature ramp1: & $50^{\circ} \mathrm{C} / \mathrm{min}$ to $150^{\circ} \mathrm{C}$ & & \\
Temperature ramp2: & $5{ }^{\circ} \mathrm{C} / \mathrm{min}$ to $180^{\circ} \mathrm{C}$ & & \\
Temperature ramp3: & $50{ }^{\circ} \mathrm{C} / \mathrm{min}$ to $80^{\circ} \mathrm{C} *$ & & \\
Final time: & $0.0 \mathrm{mins}$ & & \\
Run time: & $10.70 \mathrm{mins}$ & & \\
\hline
\end{tabular}

\section{Heartcut 1, Region 2}

$\begin{array}{ll}\text { Program: } & 2 \\ \text { Hearcut: } & 1 \\ \text { Backflush: } & 1 \\ \text { Split: } & 1 \\ \text { Split: } & 2 \\ \text { Cryotrap: } & 1 \\ \text { Initial temperature: } & 40^{\circ} \mathrm{C} \\ \text { Initial time: } & 0.5 \mathrm{mins} \\ \text { Temperature ramp1: } & 50^{\circ} \mathrm{C} / \mathrm{min} \text { to } 150^{\circ} \mathrm{C} \\ \text { Temperature ramp2: } & 5^{\circ} \mathrm{C} / \mathrm{min} \text { to } 212^{\circ} \mathrm{C} \\ \text { Temperature ramp3: } & 50^{\circ} \mathrm{C} / \mathrm{min} \text { to } 80^{\circ} \mathrm{C} * \\ \text { Final time: } & 0.0 \mathrm{mins} \\ \text { Run time: } & 17.74 \mathrm{mins}\end{array}$




\section{Heartcut 1, Region 3}

\begin{tabular}{llll} 
Program: & 2 & & \\
Heartcut: & 1 & On $=19.40 \mathrm{mins}$ & Off $=22.30 \mathrm{mins}$ \\
Backflush: & 1 & On $=22.31 \mathrm{mins}$ & Off $=44.00 \mathrm{mins}$ \\
Split: & 1 & On $=0.50 \mathrm{mins}$ & Off $=3.00 \mathrm{mins}$ \\
Split: & 2 & On $=22.31 \mathrm{mins}$ & Off $=44.00 \mathrm{mins}$ \\
Cryotrap: & 1 & On $=17.40 \mathrm{mins}$ & Off $=28.50 \mathrm{mins}$ \\
Initial temperature: & $40^{\circ} \mathrm{C}$ & \\
Initial time: & $0.5 \mathrm{mins}$ & \\
Temperature ramp1: & $50^{\circ} \mathrm{C} / \mathrm{min}$ to $150^{\circ} \mathrm{C}$ & & \\
Temperature ramp2: & $5{ }^{\circ} \mathrm{C} / \mathrm{min}$ to $225^{\circ} \mathrm{C}$ & & \\
Temperature ramp3: & $50^{\circ} \mathrm{C} / \mathrm{min}$ to $80^{\circ} \mathrm{C} *$ & & \\
Final time: & $0.0 \mathrm{mins}$ & & \\
Run time: & $20.60 \mathrm{mins}$ & & \\
\hline
\end{tabular}

* Initial oven temperature for stage 3.

Conditions for transferring the heartcut regions to OP2 and MSD from concentrated tobacco steam distillate extract (Stage 3 - GC effluent is released from cryotrap and transferred to column 2).

\begin{tabular}{llll}
\hline Olfactometer conditions & & \multicolumn{2}{c}{ GC/MSD conditions } \\
\hline Odour port: & 2 & Injection mode: & $\mathrm{N} / \mathrm{A}$ \\
Make up: & $0 \mathrm{~mL} / \mathrm{min}$ & Injection temperature: & $\mathrm{N} / \mathrm{A}$ \\
Transfer gas: & $3 \mathrm{~mL} / \mathrm{min}$ & Initial temperature: & $80^{\circ} \mathrm{C}$ \\
Humified air: & $3 \mathrm{~mL} / \mathrm{min}$ & Initial time: & $1.0 \mathrm{mins}$ \\
& & Temperature ramp1: & $5^{\circ} \mathrm{C} / \mathrm{min}$ to $240^{\circ} \mathrm{C}$ \\
& Final Time: & $15.0 \mathrm{mins}$ \\
& Run Time: & $48.0 \mathrm{mins}$ \\
& FID temperature: & $\mathrm{N} / \mathrm{A}$ \\
& MSD conditions: & $\mathrm{N} / \mathrm{A}$ \\
& Solvent delay: & 40 to $350 \mathrm{amu}$ \\
& Mass Range: & $100{ }^{\circ} \mathrm{C}$ \\
& MS Quad temperature: & $200^{\circ} \mathrm{C}$ \\
\hline
\end{tabular}

